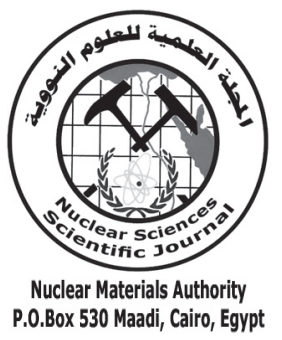

ISSN 2314-5609

Nuclear Sciences Scientific Journal

vol. 2, p 123 - 132

2013

\title{
SPECTRAL DISCRIMINATION OF URANIUM-BEARING TRACHYTE IN WADI KAREIM-WADI EL ATSHAN AREA, CENTRAL EASTERN DESERT OF EGYPT USING LANDSAT ENHANCED THEMATIC MAPPER DATA $\left(\right.$ ETM $\left.^{+}\right)$
}

\author{
MOHAMED A. EL ZALAKY. \\ Nuclear Materials Authority, P.O. Box 530, El-Maadi, Cairo, Egypt
}

\begin{abstract}
The basement rocks around Wadi Kareim-Wadi El Atshan in the Central Eastern Desert of Egypt represent a structurally and metamorphic complex assemblage of folded and faulted metasediment, metavolcanic and Hammamat sedimentary rocks into a series of trends. Geological mapping in this region is challenging, primarily due to difficult access, complexity of structures, and lack of resolution and areal integrity of lithological differentiation using conventional mapping techniques. Spectral analysis of selected bands of Landsat-7 $\mathrm{ETM}^{+}$data covered the studied area, in synergy with previous geological field observation, proved effective resolving of geological mapping problems in the study region, with emphasis on discrimination and mapping the trachyte that exposed in the area which considered as favorable host rock for uranium and/or thorium mineralization .

A variety of remote sensing processing techniques of the digital data of Landsat- $7 \mathrm{ETM}^{+}$were applied successfully for lithologic mapping in W. Kareim-Wadi El Atshan area, showing improvement in discrimination of sill, dyke and plug trachyte rocks. Not all Red, Green and Blue (RGB) band combination was useful to obtain basic knowledge of the study area. The traditional RGB $(3,2,1$ true color image and $7,4,2$ false color image) band combination could not distinguished between some outcropping units, and not delineate a definite contacts between them as well as delineation of the uranium bearing trachyte.

The adopted composite ratio image produced from combination of 3/1(Red), 5/4(Green) and 5/7(Blue) band ratios were successfully used to discriminate the uranium-bearing trachyte and demonstrate the benefit of the enhance $\mathrm{ETM}^{+}$remote sensing data for lithologic and structural mapping. While Principal Component analysis and decorrelation stretching techniques add further successful tools to outline and define the uranium-bearing trachyte that extend all over W. Kareim-W. El Atshan area.

Interpretation and observation of small exposed bodies like trachyte rocks using remote sensing techniques could help in detecting and delineating more than one localities of uranium mineralization, especially, when these data compiled and integrate with the data of favorable structural and geochemical conditions of uranium deposition.
\end{abstract}

\section{INTRODUCTION}

The study area occupies about $1200 \mathrm{~km}^{2}$ and composed mainly of metasediments, metavolcanics, Hammamat sedimentary rocks and Late tectonic granites. El Atshan uranium deposits is located at about $50 \mathrm{~km}$ to the SW of Qusseir town on the Red Sea coast, between
Wadi Dabbah and Wadi Kareim in the Central Eastern Desert of Egypt and it is important part of the studied area (Fig. 1).

Wadi Kareim-Wadi El Atshan area is the subject of many geologic and exploratory works since its discovery in 1962 by Geological Department of Atomic Energy Establish- 


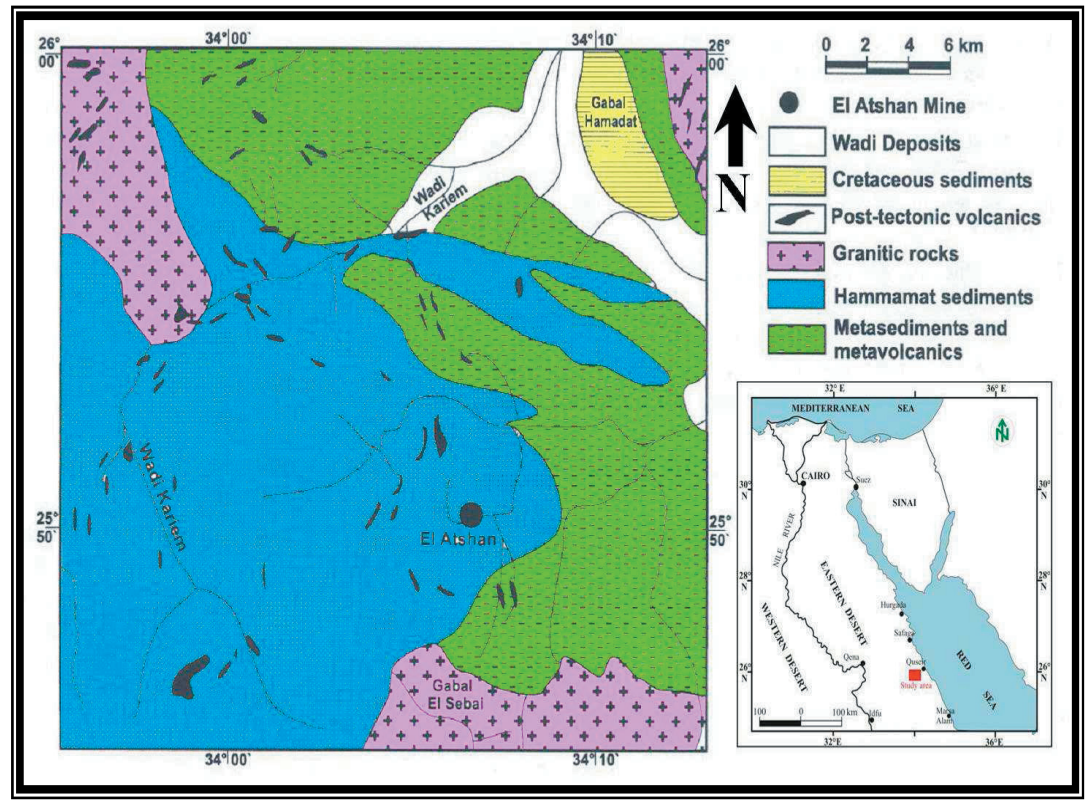

Fig. 1: Geologic map of Wadi Kareim- Wadi El Atshan area. (Modified after Dawood, et al., 2004)

ment (Nuclear Materials Authority now) as a target of uranium mineralization. Uranium deposits in volcanic rocks occurred in a variety of geological settings. A combination of supergene and hypogene processes associated with the eruption of Phanerozoic volcanic rocks have enriched the country rocks with different types of economic minerals, and therefore play an important role in the localization of uranium deposit. The mining area of El Atshan demonstrate one of the most important uranium deposits related to alkaline volcanic rocks in East Africa (Dawood et al. 2004).

The outcrops of the different rock types are traversed by some main Wadis as W. Kareim, W. El Atshan, W. Um Kurth, W. Al Tarfawi, W. Al Dabbah and W. Umm Shaghir which filled with alluvial deposits of Quaternary age.

The traditional geological mapping of this area is a challenge because of its rugged terrain and the complex structural and metamorphic history of this region. Hence, it is important to use a remote sensing data integrated with field-based geological data in order to effec- tively mapping the main lithological types in this terrain, especially the trachyte rocks that host the uranium mineralization.

Remote sensing plays an important role in geological and structural mapping as well as mineral exploration. Zumsprekel and Prinz, (2000) argue that it offers opportunity to analyze and map surface geology in a relative short time and lower cost. The remote sensing also provides a synoptic view of the study area that is often difficult to obtain from ground observation and aerial photographs alone. This study intends to use Landsat-7 data for lithologic mapping to aid in predictive mineral potential mapping of W. Kareim-Wadi El Atshan area, Central Eastern Desert, Egypt.

Reconnaissance lithologic mapping of W. Kareim-Wadi El Atshan trachyte that hosted uranium mineralization in the study area is usually the first step or preliminary study of mineral resource mapping. The use of multispectral remote sensing can help identifying and thematically map regions of exploration interest by using the distinct absorption fea- 
tures of most rock forming minerals.

Its worth to mention, that GIS, as a perfect tool in integrating and analyzing various georeferenced geoscience data, is used in this work to compare and manipulate between the previous geologic and topographic maps and the present remote sensing works in order to extract the output images of the different used techniques.

It is well known that the use of remotely sensed images cannot replace direct ground observation or data derived from field and laboratory studies. They can form integral and valuable supplements to more traditional methods and provide information and a perspective not otherwise available. Therefore, the present paper is an attempt to discriminate and mapping the uranium bearing trachyte cutting through the different rock types covering the area of W. Kareim-W. El Atshan.

\section{GEOLOGY}

The geology of El Atshan area has been investigated by Nedimovic et al.(1962). El Ghawaby et al. (1964), Obrenovic et al. (1966), Assaf (1966), El Kassas (1969), El Amin (1971), Hussein and El Kassas (1972), Osmond et al. (1999), Dawood et al. (2004) and Dardier et al. (2011). According to these authors, W. Kareim-W. El Atshan area are mainly occupied by four rock types including from older to younger: meta-sediments, metavolcanics, Hammamat sedimentary rocks, Late tectonic granites and post-tectonic volcanics (Fig. 1).

The metasediments are composed of metamudstones, schists and less common metagraywackes and gneisses. Metavolcanics subjected to folding and regional metamorphism. They are composed mainly of metabasaltic and metaandesitic sills, sheets and lenses. Hammamat sedimentary rocks consist of a group of slightly metamorphosed well-defined sedimentary strata unconformable overlying the older rocks. The Hammamat sedimentary rocks cover a large part of El TarfawyEl Dabbah area. They form a moderatly hilly topography traversed by a group of volcanic alkaline dykes and sills. The granites occupies the northwestern part of the studied area in the form of a large body intruded in Hammamate sedimentary rocks and in the southeastern part where they form G. El Sibai pluton. These intrusions constitute high and moderate peaks with sharply defined oval shaped bodies. At the contact zones of these intrusions, the country rocks are strongly altered. The posttectonic volcanics are represented by trachyte, felsite, granite porphyry, quartz veins, and less common basic rocks.

The trachytes (previously named bostonite) cropout as plugs, sills and dykes scattering allover the mapped area. The recorded sills usually occupies and follow the foliation planes of the Hammamat sedimentary rocks as at W. Al-Owayrisha, while the trachyte dykes invade tectonic mélange as at W. Kareim. The huge plugs and masses form many mountainous bodies as G. Um Khurs (912 m above sea level) and G. Nasb Al-Qash (899 m a.s.l); (Dardier et al. 2011).

Petrographically, the trachytes are finegrained consisting of alkali feldspar (sanidine) together with some mafic minerals especially hornblende, aegerine and/or mica. Most trachytes have little or no quartz. They usually show trachytic and porphyritic textures with common presence of vesicles and amygdales. Sanidine occurs as large well-shaped porphyritic crystals and smaller imperfect laths forming a finely crystalline groundmass. Some large sanidine crystals contain a considerable proportion of the sodic plagioclase (albite) forming anorthoclase or cryptoperthite (Dardier et al. 2011).

The trachyte sills at El Atshan locality intruded along the bedding planes of foliated siltstones. They range from pinkish -buff to cream yellow colour. They extend for about one kilometer with a variable thickness from 20 to $30 \mathrm{~m}$ at El Atshan area. El Manharawy, 1972 dated the trachyte age by $273 \pm 20$ m.y. (Late Carboniferous to Early Permian,). Similar ages were reported for volcanic dikes of the Wadi Kariem area (Sayyah et al., 1978). 
Primary uranium (pitchblende and coffinite) with polysulphide mineralization was reported associated with the tyrachyte in the course of the experimental mining operations carried out to follow the surfacial mineralization. The later has been encountered at the contact zones between the trachyte sill and the older Hammamat sedimentary rocks (Hussein and El Kassas, 1972). El Hazek, (1986) suggested that the sulphide minerlization was earlier than the pitchblende as a primary uranium mineral.

\section{REMOTE SENSING APPLICATION IN}

\section{LITHOLOGGIC MAPPING}

Landsat Enhanced Thematic Mapper $\left(\mathrm{ETM}^{+}\right) 30 \mathrm{~m}$ spatial resolution data for the study area was subset and processed for geological mapping using ENVI 4.7 software. A single Landsat ETM ${ }^{+}$scene (Path 174 Row 42, date acquisition 2000) covering the investigated area has been used. Digital processing of $\mathrm{ETM}^{+}$data for the study area generated several products ranging from single band images, true and false color composite images (different band combination), principle component analysis, band ratio images and decorrelation stretching.

The effective factor controlling the lithologic mapping using different remote sensing techniques is the increased concentration of minerals relative to the background in the locality and the mineral assemblage characteristics (Frei and Jutz, 1989).

\section{The False Color Composite Images}

All the band combination of true or false color composite images fail to give a good discrimination and outline the uranium-bearing trachyte within the study area. Whereas false color composite images of bands $(7,4,2)$ displayed in RGB respectively of the study area (Fig. 2) revealed that it is difficult to discriminate the trachyte bodies using such traditional band combination.

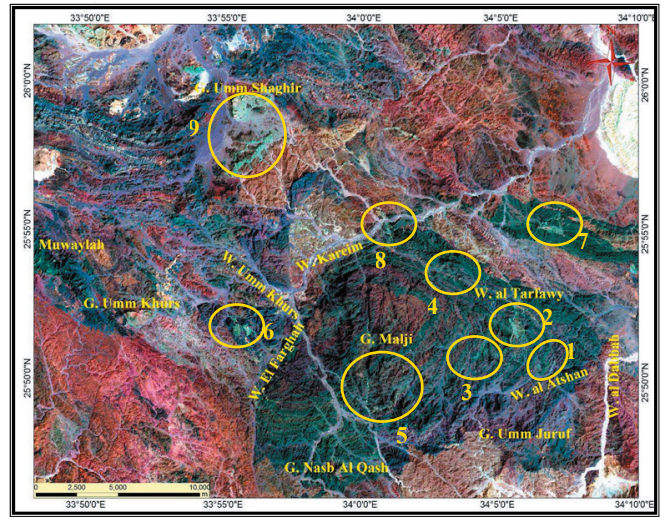

Fig. 2: False color composite Landsat ETM+ image (Bands 7, 4, 2 displayed in RGB) of Wadi Kareim- Wadi El Atshan area Trachyte location (1: El Atshan area, 2: W. Um Rahia, W. Ghawaby and Abu Shlawlaw area, 3: Abu Ghadir, Um Sweider, 4:NW W. Kab Amni, 5: South G. Malji, 6: El Farkha area 7: SE Shaykha Amni, 8: Noth Talat Al Uwersh and 9: G. Umm Shaghir)

\section{Principal Component Analysis (PCA)}

Most data of multispectral bands are often correlated i.e. have similar visual appearances, especially for the felsic rocks. Image transformations techniques based on complex statistical processing for multi-band data sets can be used a number of bands to reduce the data redundancy and correlation between them. This is called principal components analysis. Although, it is more difficult to display more than three band combination as color composite image, the principal component is a technique for displaying the maximum spectral contrast from n-spectral bands with just three primary display colors (Vincent, 1997).

The principal component analysis was carried out for remote sensing data covering the studied area. The PCA was applied on the non-thermal $\mathrm{ETM}^{+}$six bands $(1,2,3,4,5$ and $7)$ of the selected areas. The analysis of these data produces four principal component bands ordered in terms of decreasing the information content using the calculation of covariance matrix. The eigen values and variances \% of the result PCA were calculated and shown in Table (1). These components could be display separately as single stretched PC-images or as component in color composite PC-image. 
Table 1: Eigen-values and Variances \% of the ETM+ subset data of the studied area

\begin{tabular}{lrr} 
PCA & Eigen values & Variance \% \\
\hline PC1 & 978.244 & 90.83 \\
PC2 & 77.777 & 7.22 \\
PC3 & 11.327 & 1.05 \\
PC4 & 6.064 & 0.57 \\
\hline
\end{tabular}

The calculated eigen-values show that PC1 include the largest variance percentage $(90.83 \%)$ of the all information content of the subsecne of this area whereas PC2, PC3, and PC4 mark $7.22 \%, 1.05 \%$ and $0.57 \%$, respectively. The fourth principal component (PC4) of this area was found to highlight and characterize the trachyte bodies whereas they appear more bright than the surrounding rocks.

The false color composite PC-image of studied area was constructed using combination of PC4, PC3 and PC1 display in RGB, respectively (Fig. 3). The uranium-bearing trachytes could be outlined and discriminated from the other rock types, whereas their spectral signature allover the study area posses a pale red to rose color (Fig. 3). This could be reflect that the spectral signature variance of trachytes are compressed in PC4 that display in red channel.

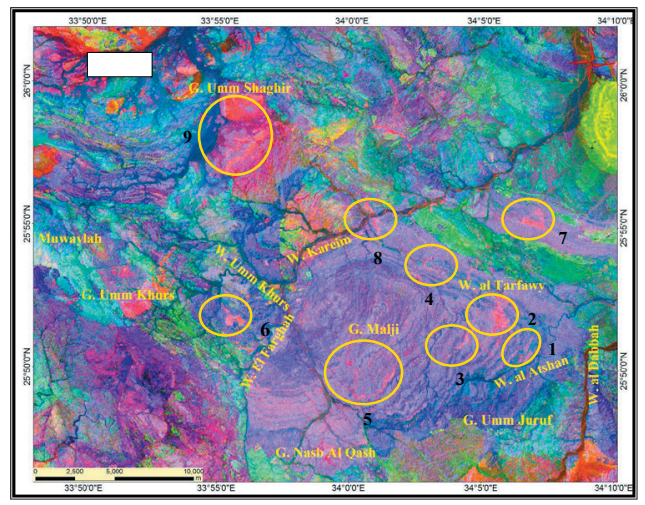

Fig. 3: False color composite image of principal components PC4, PC3, PC1 displayed in RGB for Wadi KareimWadi El Atshan area Trachyte location (as in Fig. 2)
It is clear that this false color composite PC-image delineated and mapped most of the trachyte bodies of the different localities such as 1: El Atshan area, 2: W. Um Rahia, W. Ghawaby and Abu Shlawlaw area, 3: Abu Ghadir, Um Sweider, 4: North West of W. Kab Amni, 5: South G. Malji, 6: El Farkha area, 7: South East Shaykha Amni, 8: North Talat Al Uwersha and 9: G. Umm Shaghir which delineated in the image by yellow circles (Fig. 3).

\section{Band Ratios}

Mapping of the different rock units using remote sensing images have been carried out using different techniques, one of which is the band ratio method. Band ratio is a technique that has been used for many years in remote sensing to effectively display spectral variations. Band ratios are assumed to overcome the shadow and topography effects, because the ratio of reflectivity of any two bands for a given material is not a function of illumination. However, other information on spectral differences could have been enhanced by this manipulation

The band ratio technique is the ratio of one band to another. It is prepared simply by dividing the digital number (DN) of each pixel in one band by the DN of another band (Drury, 1987), and the resulting new values are plotted as images. The main advantages of ratio images are that they used to reduce the variable effects of illumination condition, thus suppressing the expression of topography (Crane, 1971). Also, band ratio is a data of compressive nature, thus band ratio images are less correlated and chromatically enhanced than original $\mathrm{ETM}^{+}$bands.

Many authors dealt with the lithologic mapping using ratio images which applied for the TM images, among them,e.g. Abrams et al., 1983; Kaufmann, 1988; Abdelsalam and Stern, 1999; Sultan et al., 1986; Kusky and Ramadan, 2002; Gad, 2002; Gad and Kusky, 2006; Frei and Jutz, 1989; and Sabins, 1999.

It worth to mention that El Rakaiby 1995 applied a proposed band ratio and multiplication image of Landsat TM imagery (2/4x7, 5/7x3 and 5/3x7 in RGB respectively) for an area covering a part of the Central 
Eastern Desert of Egypt. This proposed band ratio were succeeded in discrimination and classification of the younger granites into three groups. He also succeeded in recognizing the alteration zones associated with the shear zones that host uranium mineralization within G. El Missikat and G. El Eradiya area.

In the current study we propose a new band ratio combination by using Landsat Enhanced Thematic Mapper $\left(\mathrm{ETM}^{+}\right)$image. The new proposed band ratio has been tested for its effectiveness to discriminate the trachyte bodies that hosting uranium mineralization. This proposed band ratios $(3 / 1,5 / 4$ and $5 / 7$ in $R G B$ respectively) was succeeded in discrimination of different localities of trachyte bodies. Whereas the spectral features signature of the uranium-bearing trachytes of the studied area are displayed in this image by shining red color as shown in the areas that marked by yellow circles (Fig. 4). The results revealed that, by using the proposed band ratio, it was so effective to discriminate nine localities of trychyte bodies that cutting through the different rock type within the study area.

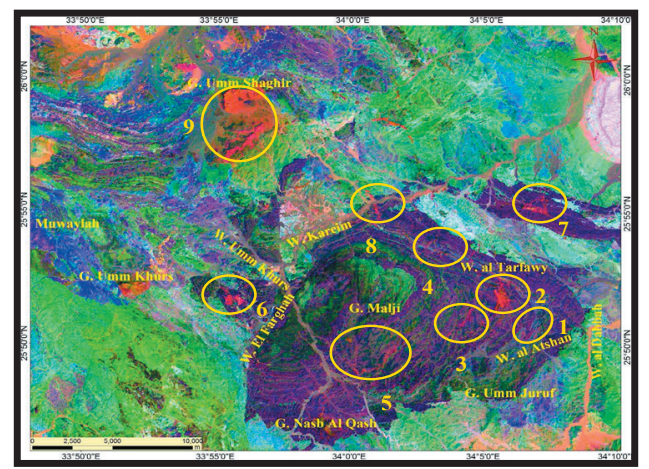

Fig.4: False color composite ETM+ ratio image (3/1, 5/4, $5 / 7$ in $R, G, B)$ of Wadi Kareim- Wadi El Atshan area Trachyte location (as in Fig. 2)

The trachyte bodies appear in red color because they have high reflectance in band ratio $3 / 1$ and low reflectance in both band ratio $5 / 4$ and $5 / 7$. This could be interpreted by less abundance of mafic and hydroxyl-bearing minerals such as hornblend and boitite while these trachyte bodies are occasionally stained by hematitization.

\section{Decorrelation Stretching}

One of the difficulties in color contrast enhancement is spectral band correlation. If three correlated bands are displayed, their data distribution lies nearly along a line in the color cube, from the darkest pixels to the brightest ones, and very little of the available color space is utilized. If we decorrelate the bands, stretch the PCs to better fill the color space, and then inverse transform to the RGB color space, we will enhance whatever spectral information is present in the data. This idea is the basis of the PCT decorrelation stretch (Gillespie et al., 1986; Durand and Kerr, 1989 and Rothery and Hunt, 1990).

Applying the Decorrelation Stretch technique to the remotely sensed data of the study area is successfully helped in removing the high correlation commonly found in multispectral data sets and produce a more colorful composite image. The highly correlated data sets often produce quite bland color images. Decorrelation stretching requires three bands for input. Figure (5) showed that the decorrelation of band 3,5 and 1 displayed in RGB respectively was successfully highlight the trachyte bodies within the study area whereas spectral feature signature of these bodies could be indicated in this image by shining red color. Different localities of trachyte bodies could be mapped and delineated by using this technique

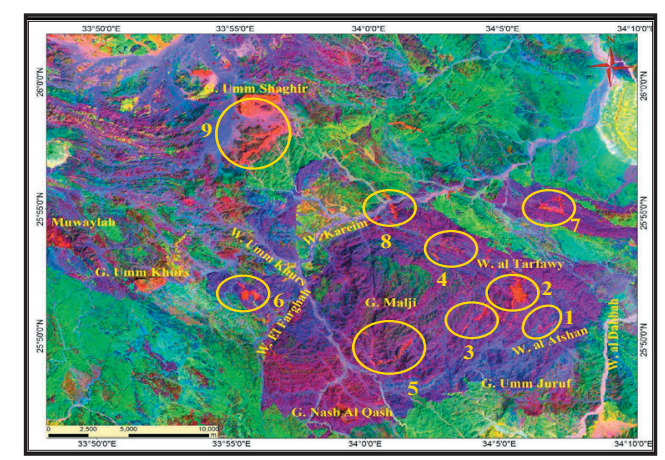

Fig. 5: False color composite image of Landsat ETM+ decorrelation stretching of band 3,5,1 displaye in RGB of Wadi Kareim-Wadi El Atshan area Trachyte location (same as in Fig. 2) 
which appear as red bodies cutting through the different rock types allover the study area (yellow circles on Figure 5).

\section{A PROPOSED STRUCTURAL} PATTERN USING REMOTE SENSING

Satellite images and aerial photos are among continuous sources of data for mapping structure which frequently reflect surfaces of discontinuity in the rocks. The synoptic view and interpretation of the ratio composite image 3/1, 5/4, 5/7 displaying in RGB respectively successfully used to delineate the structural elements of the studied area. Therefore, the area of W. Kareim-W. El Atshan is subjected to polyphase deformation which acquires two phases of folding namely $\mathrm{F} 1$ and F2. The area is characterized by the presence of metasediments (ophiolitic mélange matrix), metavolanics, Hammamat Molasse sediments as well as post tectonic volcanic and related trachyte (El Ramly 1972). The Hammamat molasse sediments are noticed to be affected by the two phases of deformation (Fig. 6).

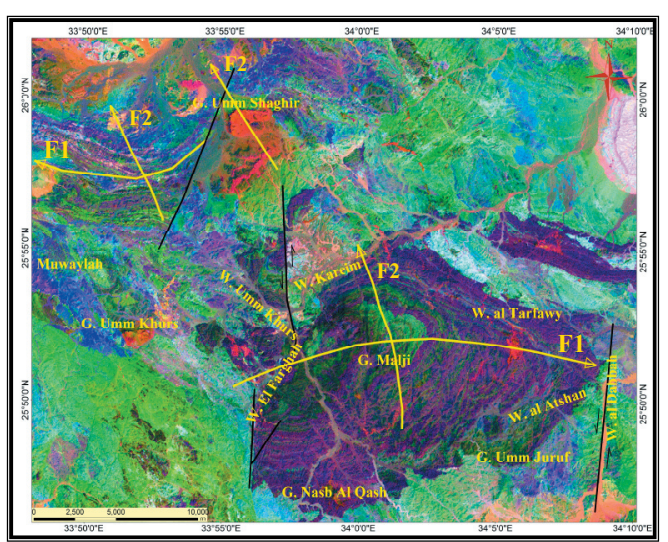

Fig. 6: Major structural elements at Wadi Kareim-Wadi El Atshan area

The $1^{\text {st }}$ phase of them $(F 1)$ is characterized by tight abressed folds whose axes are trending ENE-WSW. On contrast, the $2^{\text {nd }}$ phase (F2) is represented by open gentle folding whose axes are trending NNW-SSE. These two phases of folding are well developed in Hammamat sediments of G. Malji and metasediments west of G. Shaghir respectively (Fig. 6). The folding mechanism are suggested to be related to double shears that is caused due to the movements along the N-S shear zones (stage 1, Fig $7 \mathrm{a})$. This cause double plunging en'echelon folds (stage 2, Fig 7b). When these structures are eroded, the Hammamat sediments and the enclosed trachyte sills and dykes are exposed in different patterns according to their location in the overall structure (stage 3, Fig 7c).

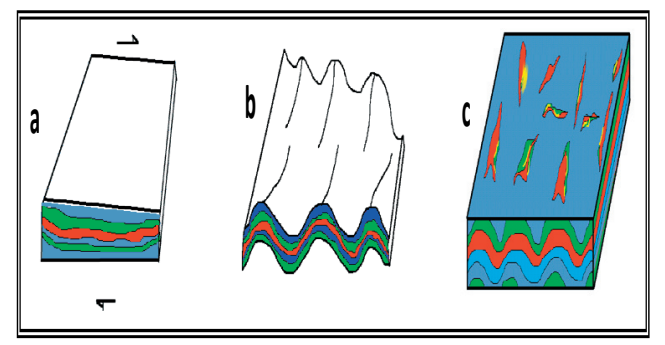

Fig.7: Model diagram showing the successive stages of deformations of the Hammamat series (green and blue color) enclosed sills of trachytes (red color layer), (a) Hammamat sedimentary rocks injected by sill of trachyte and subjected to double shear (b): double plunging en'echelon folds are developed, (c): after the erosion of the crests of the double plunging en'echelon folds and the distribution of the bostomite exposures.

From the proposed structural model that extracted from the satellite image, it could be interpreted that they are injected by trachyte prior to the deformation of the Hammamat sediments. Most of this volcanic layer are concordant to the bedding and layering of the Hammamat sedimentary rocks and folded with them during the subsequent phases of folding. This proposed structural vision must be insured and proved by extensive structural field work in the bases of structural domains.

It is worth to mention that this study succeeded in delineate a U-shape trachyte body intruding the Hammamat sediments south G. Melji. This U-shape of trachyte body located near the core of F1 folding phase and at the core of F2 folding phase which could represent a good target of favorable structural elements that help in localization of uranium mineralization within this area. 


\section{CONCLUSION}

The recent development of multi-spectral remote sensing techniques such as Landsat $\mathrm{ETM}^{+}$, gain real information and potentially offers geologists a cost-effective solution method for lithologic and structural mapping. In the current study, there are three image processing techniques that used to highlight and discriminate the trachyte bodies in different localities and mapping the major structural features prevailing in the area. The results show that a main nine trachyte bodies were discriminate and delineate allover the study area. The result data was calibrated using previous maps as well as field investigation. This study succeed in delineate and discriminate a new occurrence of trachyte bodies located south to G. Melji which represented by U shape belt of trachyte sill injected into the hammamat sediments. This occurrence have the longest extension of trachyte bodies allover the area, and could be represent a good target of uranium occurrence because it located near the core of major fold of G. Melji. The applied combination of Landsat $\mathrm{ETM}^{+}$band ratios allowed clear color variations that express more geologic information and great contrast between the different rock types that help in recognition of major structural elements affecting the study area.

The author recommend more detailed study on the uranium bearing trachytes and their associated favorable geological structural elements allover the study area, with emphases on the area south G. Melji, in the near future using more recently and advanced remote sensing data.

\section{REFERENCES}

Abdelsalam, M.G., and Stern, R.J.,1999. Mineral exploration with satellite remote sensing imagery; examples from the Neoproterozoic Arabian Sheild. J. Afr. Ear. Sci., 28, 4a.

Abrams, M. J.; Brown, D.; Lepley, L.; Sadowski, R., 1983. Remote sensing for porphyry copper deposits in southern Arizona. Econ. Geol., 78, 591-604.
Assaf, H.S.,1966. Ground exploration and geological studies of some radioactive occurrences in the area south of Quseir. M.Sc Thesis,Fac. Sci., Ain Shams Univ., Cairo, Egypt.

Crane, R.B.,1971. Processing techniques to reduce atmospheric and sensor variability in multispectral scanner data. Proc. $7^{\text {th }}$ Inter. Symp. Rem. Sens. Env., Ann Arbor, 2, 1345-1355.

Dardier, A.M.; El-Mansi, M.M.; Farag, S. S.; Abdel Ghani, I.M.; Mohammaden, I.M.; El-Balakssy, S.S.; El-Sawey, E.H.; Hamed, A.A.; Omeran, A.A.; Abdel Fattah, M.F.; Dessoky, O.K., and Zher, F.Y., 2011. Uranium prospecting. In: W.Kareim - W.Zaydun area, Eastern Desert, Egypt. Internal report NMA, Egypt.

Dawood, Y.H; Abd El Naby, H.H, and Sharafeldin, A.A,2004. Influence of the alteration processes on the origin of uranium and europium anomalies in trachyte, central Eastern Desert, Egypt. J. Geochem. Explor., 88,15-27.

Drury, S. A.,1987. Image interpretation in geology. $1^{\text {st }}$ Ed., (Allen\&Unwin) London ,243p.

Durand, J. M., and Kerr,Y.H.,1989. An improved decorrelation method for the efficient display of multispectral data. IEEE Transactions on Geoscience and Rem. Sens., 27(5), 611-619.

El Amin, H.,1971. Structural controls of the radioactive mineralization in the Central Eastern Desert. M. Sc. Thesis, Fac. Sci., Cairo Univ., $100 \mathrm{p}$.

El Ghawaby, M.A.; Badr, A., and El Amin, H., 1964. Report on the results of drilling at uranium occurrence of El Atshan locality, Central Eastern Desert. Internal Report, U.A.R. Atomic Energy Establishment, Cairo.

El Hazek, N.M.,1968. The primary ore at El Atshan and its physical and chemical properties (with special technological application).Ph. D. Thesis, Fac. Sci., Ain Shams Univ.,

El Kassas,I.A.,1969. Comparative geological investigation of the radioactive mineralization in the central Eastern Desert, Egypt. U.A.R. M. Sc. Thesis, Fac. Sci., Ain Shams Univ., Cairo, Egypt. 
El Manharawy, M.S.,1972. Isotopic ages and origin of some uranium bearing volcanic rocks in Egypt. M. Sc. Thesis,Fac. Sci., Cairo Univ.

El Rakaiby, M.L.,1995. The use of enhanced Landsat-TM image in the characterization of uraniferous granitic rocks in the Central Eastern Desert, Egypt. Inter. J. Rem. Sen., 16(6), 10631074.

El Ramly, M. F.,1972. A new geological map for the basement rocks in the Eastern and Southwestern Deserts of Egypt, Scale 1:1000000. Ann. Geol. Surv. Egypt, II, 1-18.

Frei, M., and Jutz, S. L.,1989. Use of Thematic Mapper data for the detection of gold bearing formations in the Eastern Desert of Egypt. Proc. $7^{\text {th }}$ Thematic Conf. Remote Sensing for Exploration Geol., Environmental Research Institute of Michigan, Ann Arbor, Mich., II,1157-1172.

Gad, S., and Kusky T.,2006. Lithological mapping in the Eastern Desert of Egypt, the Barramiya area, using Landsat Thematic Mapper (TM). J. Afr. Ear. Sci., 44, 196-202.

Gad, S., 2002. Exploration for mineralized granites in Central Eastern Desert, Egypt. M.Sc. Thesis, Fac. Sci., South Valley Univ., Aswan, Egypt, $118 \mathrm{p}$.

Gillespie, A. R.; Kahle, A. B., and Walker, R. E. ,1986. Color enhancement of highly correlated images. I. Decorrelation and HSI contrast stretches. Rem. Sen. Env., 20, 209-235.

Hussein, H.A., and El Kassas, I.A.,1972. Occurrence of some primary uranium mineralization at El Atshan locality, central Eastern Desert, Egypt. J. Geol. 14(2), 97-110.

Kaufmann, H., 1988. Mineral exploration along the Aqaba-Levent structure by use of Landsat TM data; concepts, processing, and results. Inter. J. . Rem. Sen. 9, 1639-1658.

Kusky, T.M., and Ramadan, T.,2002. Structural controls on Neoproterozoic mineralization in the south Eastern Desert, Egypt; an integrated field, Landsat TM, and SIR C/X approach. J. Afr. Ear. Sci. 35, 107-121.

Nedimovic, R.; Hussein, H.A., and Obrenovic, M.,1962. Report on the prospection for uranium. Internal Report, Geol. and Nuclear Row Materials Dep., Arab Republic of Egypt, Atonic Energy Establishment, Cairo, Egypt.

Obrenovic, M.; El Kassas, I. A., and El Amine, H.,1966. Report on the results of detailed exploratory mining works at the uranium deposit of Wadi El Atshan locality. Central Eastern Desert. Internal Report, U.A.R. Atomic Energy Establishment, Cairo.

Osmond, J.K.; Dabous, A.A., and Dawood, Y.H.,1999. U series age and origin of two secondary uranium deposits, Central Eastern Desert, Egypt. Econ. Geol. 94, 273-280.

Rothery, D. A., and Hunt, G. A. ,1990. "A simple way to perform decorrelation stretching and related techniques on menu-drive image processing systems." Inter. J. Rem. Sen.,11(1), 133-137.

Sabins, F. F., 1999. Remote sensing for mineral exploration. Ore Geol. Rev. 14, 157-183.

Sayyah, T.A.; Hashad, A.H.,El Manharawy, M.S., 1978. Radiometric $\mathrm{Rb} / \mathrm{Sr}$ isochron ages for Wadi Kareim volcanics. Arab J. Nucl. Sci. Appl. 11, 1-9.

Sultan, M.; Arvidson R.E., and Sturchio N.C.,1986. Mapping of serpentinites in the Eastern Desert of Egypt by using Landsat thematic mapper data. Geol., 14(12), 995-999.

Vincent, R. K., 1997. Fundamentals of Geological and environmental remote sensing. PrenticeHall, Inc, U.S.A., 366p.

Zumsprekel, H., and Prinz, T.,2000. Computer enhanced multispectral remote sensing data; $\mathrm{A}$ useful tool for the geological mapping of Archean terrains in (semi) arid environments. Computers and geosciences ,26, 87-100. 
التمييز الطيفى لصخور التراكيت الحاوى لليورانيوم بمنطقة وادى كريم - وادى العطشان ، وسط الصحر اءعاء الثرقية ،

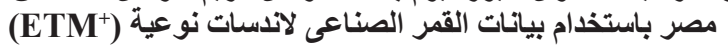

$$
\text { محمد علي الزلقي }
$$

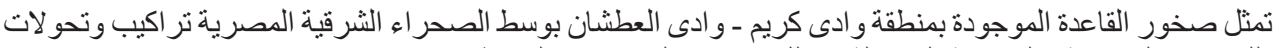
معقدة للصخور الرسوبية و البركانية المتحولة وكذللك صخور الحمامات والتى طويت جميعها وتصدعت فئ في اتجاهات عديدة.

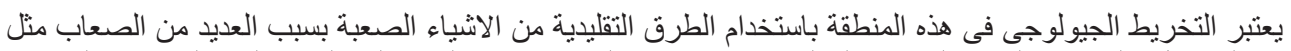

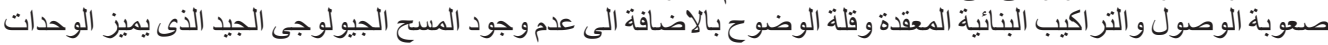
الصخرية.

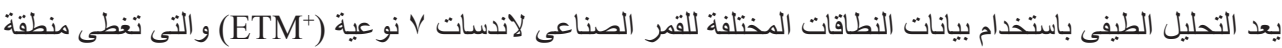

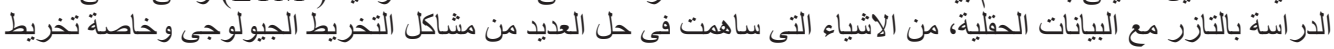
التر اكيت الحاوى لليور انيوم.

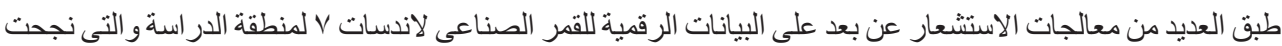

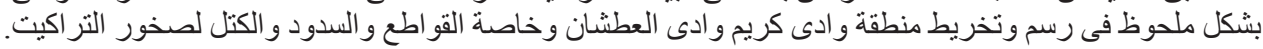

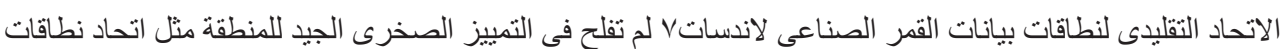

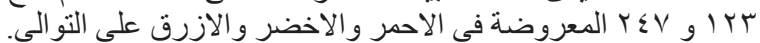

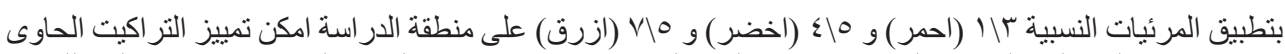

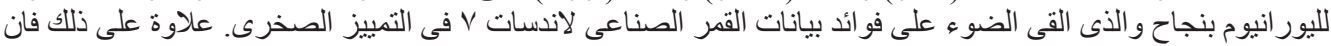

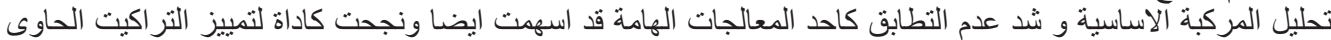

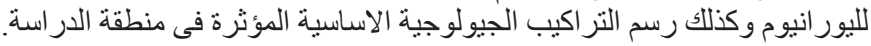

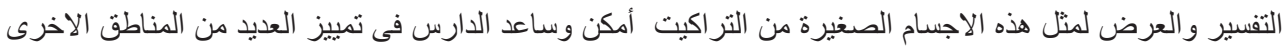

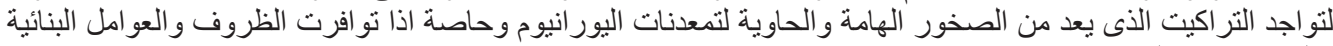

